\title{
Sufism Shat'h versus Surrealism Literature and Art
}

\author{
Zahra Abdollah \\ * http://dx.doi.org/10.4314/ujah.v15i2.4
}

\begin{abstract}
Resemblance of Surrealism and Sufism is very exciting. Surrealism, the influential avant-garde movement and offspring of 20th century Modernism, strives for truth by plumbing depths of psychic plane and going beyond concrete reality. Sufism, the Islamic mystical discipline, as well, involves a spiritual pilgrimage toward the Absolute Unity above and beyond all created real objects. Confrontation with supra-reality leads to similar paradoxical symptoms in both Surrealism and Sufism expressions. Pertinently, disclosures of Surrealists manifest in their art and literature; and present article tends to compare their substratum, principles and methods with those of Sufi's ecstatic and theopathetic exclamations or shat'h. The comparison digs for deeper sources from which both Surrealism and Sufism flow, as they are believed to overlap hitherto.
\end{abstract}

\section{Introduction}

The allegorical language of Surrealist literature and art and Sufi shat' $h$ share many crucial features in the context of form, as much as the form is concerned, in which verbal and visual message would not permit commonsense interpretations. This is partly because both atheistic Surrealism and monotheistic Sufism seek expansion of the totality of human potential and liberation of mankind from all limitations and repressions. To 
attain such extension, the former prescribes drug and hypnosis experiments whereas the latter stipulates self-combat, $d h i k r$ and sam $\bar{a}$. In fact, through these spiritual yearnings the Sufi is expected to achieve a degree of purification and maturity, so as to love whole creation as manifestation of one primordial Beloved. In Surrealism, love denotes, at the most, a carnal passionate sexuality. In fact, Surrealism aspires to appreciate not only love but also everything irrational. Presumably, defiance of rationalism is the most common aspect of these two arenas, a trend which other commonalities profoundly steep in. To corroborate the presumed resemblance, designated Surrealism principles, as classified by Duplessis (Duplessis, 1978) and reviewed by Esmaili (Esmaili, 2006), and their emergence in Sufism is going to be thrashed out.

\section{Defiance of Rationalism.}

Surrealism, implanted in the matrix period between two World Wars, attempted to awaken society by disparaging permeated rationalism and destruction that culminated in the horrors of World War I. Inspired by the psychoanalytic speculations of Freud, surrealists exploited irrationalistic states of mind as an enabler of social transformation. This led them to admire everything that defies rational thinking, including not only dream and chance but also, for this reason, spiritism, esoterism, chaos, "wild" and "primitive" personalities, everything non-Western, sadism, perversions, crime and even serial killers and mad or out of mind people. They did all these in opposition, of course, to the prevailing capitalist order, as well as the widespread dominance of rationalism. André Breton, the founder of the surrealist movement, wrote in Manifestoes of Surrealism that with the abandonment of "absolute rationalism" the human imagination would be "on the verge of recovering its rights" (Breton, 1972, 66). In Nadja, the first and known to be the 
best surrealist romance ever written, Breton blames the contemporary social system for confining madmen in sanitariums and depriving them of freedom (Breton, 1960, 139-141). He adds "the well-known lack of frontiers between non-madness and madness does not induce me to accord a difference to the perceptions and ideas which are the result of one or the other" (ibid, 144). Elsewhere, Breton declares "I am not afraid to advertise the idea, paradoxical only at first sight, that the art of those who today are in the category of mentally sick constitutes a reservoir of moral health."(Eve, $1970,10)$ In fact, in the surrealism eyes, madness itself has assumed the statues of art form.

Sufism, on the other hand, does not propagate freedom of madmen, though does praise madness, out of mindedness and renouncement of reason, intellect and discursive knowledge or 'aql. Mystics recurrently refuted philosophy and theology for their excessive reliance on logic and reason. Rumī, master of ecstatic experience of love and whom AnvarChenderoff calls shattāh, sets the idea to verse: I examined the provident intellect; from now on I will madden myself (Mathnavi, Book 2, verse 2332). The same theme reappears in verse 2337 and other occasions.

\section{Chance and Automatism.}

Automatic writing and painting is a method by which surrealists believed to suppress conscious control and interest over imagination and movements of hand. They, lingering over accidents, chance occurrences, whims, hunches and moments that appear to break the pattern of events, would write as quickly as possible. "Their anomalous randomness deprives them of meaning, yet their singularity fills them with heightened significance and even ominousness." (Nadeau, 1968, 20)

In fact, "Pure psychic automatism" was how André 
Breton defined surrealism, and while the definition has proved capable of significant expansion, automatism remains of prime importance in the movement. The most famous artists who practiced chance driven automatic painting include André Masson, Joan Miró, Salvador Dali, Jean Arp and André Breton; and among writers, Lautréamont, was the first and foremost of Surrealism's literary precursors. The following text is from his Maldoror:

...One should let one's nails grow for a fortnight. Oh! How sweet it is to brutally snatch from his bed a child with no hair yet on his upper lip, and, with eyes wide open, to pretend to suavely stroke his forehead, brushing back his beautiful locks! Then, suddenly, at the moment when he least expects it, to sink one's long nails into his tender breast, being careful, though, not to kill him; for if he died, there would be no later viewing of his misery. Then, one drinks the blood, licking the wounds; and, during the entire procedure, which ought to last no shorter than an aeon, the boy cries... (Lautréamont, 2004)

In Sufism history there had been spiritual occasions in which highly intoxicated Sufis, like Rūmī and Junayd, flared up with sublime outpourings. Where the former's automatism ensued to the most delicate divine poems of Sufism history, the latter, stricken by his unconscious revelations, was cautious to utter these words publicly. Nonetheless, Junayd's writings are highly accepted within Sufism. Here is a fragment of his treatise in which he provides a dense discussion of mystical union. As Sells appoints it, too, might be viewed as "a kind of automatic writing, a stream of ...transconciousness, or an interlocking progression along a mobious strip." (Sells, 1996, 252) 
...He (Allah Almighty) indicates himself through himself. The cause of this indication ... is his granting of success. From his granting of success occurs the affirmation of unity; from affirmation of unity occurs affirmation of his truth; from affirmation of truth, realization; from the realization of him, the knowing of him, begging a response from him to prayers; from begging a response, a refinement toward him,...Then he was, after he was not, whereby he was-was! He was he after he was not he. (Sells, 1996, 254)

\section{Satire}

Surreal humor or satire is a form of humor, stylistically related to the artistic ambitions of the surrealists, based on bizarre juxtapositions, absurd situations and nonsense. A common element of surreal humor is the non-sequitur, in which one statement is followed by another with no logical progression.

In 1937, Breton edited an anthology on l'humor noir, or black humor, which featured rebellion against intellectuals and influenced such writers as Swift, Kafka, Rimbaud, Poe, Lewis Carroll and Baudelaire. Like other surreal writers, Edward Lear's nonsense stories and poems are filled with contradictory statements and odd images intended to provoke amusement, such as the following:

They were, however, able to catch numbers of the chickens and turkeys, and other birds who incessantly alighted on the head of the Rhinoceros for the purpose of gathering the seeds of the rhododendron plants which grew there, and these creatures they cooked in the most translucent and satisfactory manner, by means of a fire lighted on the end of the 
Rhinoceros' back. (Lear, 1967)

Sufis, likewise use humor in their literature, however for a moral admonishment or ethical-spiritual purposes. Rumī in his Mathnaw $\bar{l}$ illustrates a story of a tanner who was accustomed to bad smells in the course of his trade, and who was half killed by the smell of musk in the bazaar of the perfumers, but was finally cured by the accustomed smell of dung.

...Your lust is as fire in the world,

With a hundred greedy mouths wide open.

In the judgment of reason this gold is foul dung,

Although, like dung, it serves to kindle the fire

Whoso was born in the stove-room and never

saw purity,

The smell of sweet musk is disagreeable to him (Rumī, 1898)

Marvelous and Extraordinary Things. The marvelous in relation to Surrealism, as Pierre-Albert Birot put it, "Performs the miracle of blending itself with the ordinary and commonplace in the most natural way in the world" (Duplessis, 1978, 36). It is in these everyday objects that beautiful and simply amazing things lie. Surrealism lifts up the cover, which clothes objects, and tries to reveal what is underneath, which is the marvelous. Duplessis also explains, "the Surrealists invite us to step beyond the utilitarian world where material gain is the prime motive, so that we can set foot in another world, altogether marvelous and mysterious. Surrealism is the expression of our will for the total dissociation of everything from everything. (ibid, 28) Poems of Arthur Rimbaud, an exemplary surreal author, efficiently designate such effect: 
While public funds evaporate in feasts of fraternity, a bell of rosy fire rings in the clouds...Grey skies of crystal. A bizarre design of bridges, now straight, now curved, and others descending in oblique angles to meet the former, and these patterns repeating themselves in other well-lit windings of canal, but all so long and weightless that the shores, weighted with domes, sink and contract ...(Rimbaud, 1974)

Sufism, as it denotes, is a path from exoteric facet to the concealed esoteric dimension. While the Sufi succeeds, more and more veils tear asunder before his eyes and he discerns the extraordinary beings and perceives the marvelous existence. Shams, Rumî's master, asserts that "I witnessed waves of light surging down the sky. The feathers shed from my face and eyes and I saw through my lung and liver.'(Shams, 1998) In fact this kind of feather loss and watching one's lung and liver is quite eccentric and can be achieved only by liberating the mind and imagination. (Esmaili, 2006, 52) Another akin absurd observation is accounted by Bāyazīd :

As soon as I arrived at his oneness, I became a bird whose body was of unity and whose wings were of everlastingness. So I continued to fly through the ether of howness (kayfiyya) for ten years until I came to the air of something like that one thousand thousand times. I did not cease flying until I came to the field of pre-eternity and saw there the tree of unity... (Sells, 1996, 219)

\section{Ready-mades.}

Surrealist exploitation of ready-made components, namely collage, challenges tradition. However this modus operandi 
"cannot be reduced to a cutting and pasting technique, a material practice of collating distant realities. It is also, and more essentially, a creative act of detournément, through the subversive manipulation and creative transformation of readymade elements, forging the surreal out of fragments of real, suggesting the mervéilleux through the combination of banal and defunct images, clichés and rewritten texts. It is essentially a semiotic practice of transforming pre-formed iconic or verbal messages". (Adamowicz, 16) In fact through this exquisite assemblage "man releases himself from the world of dismal reality, so that he can penetrate the world of the disjointed and the strange."(Duplessis, 1978, 49) Breton's text, Poeme, is an example of language game played by the surrealists, consisting of poems made up of words and phrases cut out of newspapers. The following poem is from Hans Arp, a surrealist sculptor, painter and poet. (Gascoyne, 1978)

\section{The Domestic Stones (fragment)}

The feet of morning the feet of noon

and the feet of evening

walk ceaselessly round pickled

buttocks on the other hand the feet of

midnight remain motionless

in their echo-woven baskets

consequently the lion is a diamond on

the sofas made of bread

are seated the dressed and the

undressed...consequently the tail is an

umbrella

a mouth opens within another mouth

and within this mouth another mouth...

and so on without end

it is a sad perspective

which adds an I-don't-know-what 
to another I-don't-know-what

consequently the grasshopper is a column

the pianos with heads and tails

place pianos with heads and tails

on their heads and their tails

consequently the tongue is a chair

In the realm of Sufism, the ultimate goal of wayfarer is to perceive (attain) the union, albeit after annihilation in God ( $f a n \bar{a}$ ') and subsistence to God (baqā'). It is through these ostensibly paradoxical stages that the contradiction of object and subject dissolves, physical desire ends in spiritual satiation, weakness is an expression of power and pain is also pleasure. To the Sufis who arrive there, the veils torn asunder and they witness marvelous and extraordinary things that are concealed to the eyes of strangers. The story of Bāyazīd's Mira'j (heavenly ascent), mentioned by Hujvīrī, Attār and others, alludes to some of these astonishing visions.
Allah...turned me to a bird, each wing feather of which was greater than the distance from East to West one thousand thousand times...The angel had a column of light...He said: Take the column. As soon as I took it, the heavens and everything in them were sheltered in the shade of my ma'rifa...I was received by angels with eyes as numerous as the stars. (The light of the eyes) became lamps...(Sells, 1996, 248)

\section{Dreams}

The dream in relation to Surrealism questions reality. In order for surreal writing to take place, the writer has to clear the mind and forget about the outside world, possibly through isolation. In this dreaming state of the mind, "the external 
world slips away to such a degree that any interruption to the writing is like an abrupt awakening."(Duplessis, 1978, 52)

Dali once commented, "By day we unconsciously search for the lost images of our dreams, and that is why, when we find such an image, we believe we are already familiar with it, and say that to see it is to dream." (ibid, p.38) For a surrealist, the rationality of nightmare and dream seems more real since it is created through our own mind; it represents perfection because it is created through our thoughts alone and nothing else. Pertinently, dreaming is just as important as thinking because you can learn just as much from dreaming as from thinking. Some Surrealists also wondered if dreaming was just another form of wakefulness, where we continue our "reality" each time we fall asleep. In the following fragment of Breton's poem, the poet in a dream-like boating adventure, heeds how the strings of an instrument has entrapped the musician.

...I have a boat detached from all climates

I am dragged along by an ice-pack with teeth of

flame

I cut and cleave the wood of this tree that will always be green

A musician is caught up in the strings of his instrument ...(Gascoyne, 1978)

For Sufism dreaming is a state of ecstasy in which distinctions dissolve into union. For example according to Bāyazīd, his ascendance to heaven occurs in such a state. (Sells, 1996, 244) In fact what they reveal in these states is sometimes very contradictory to the sharī'ah, even Bāyazīd, astonished by his own utterances (which his disciples retold him) asks his disciples to stab him if they heard the same utterance from 
him next time. However the best way to know the mystical rank of some Sufis is to regard their dream and vision. Here are two famous shat'hs which brought infidelity allegation and heresy trial to their declaimers (Nūrī, Hallāj, Ayn ulGudāt):
"I am the Real", said Hallāj
"Glory to me, Glory to me, how majestic I am", said Bāyazīd

The aforementioned argument elucidates the resemblance between two realms: Surrealism, as a western movement yet affected by eastern gnosis, Zen ethos and Indian culture; and Sufism, "not as the English word implies, an "ism" or theory, but rather a living experience and a quest for perfection." (Ernst, 1985, 1) Notwithstanding, the superficial similarity of techniques, by no means, should mislead to the equivalency of goal and approach. As a matter of fact, Surrealists were heavily fascinated with psychology and, further into the subject, psychoanalysis speculations of Sigmund Freud. Freud used psychoanalysis to uncover the hidden truth of man. He believed that sexual desire was the main drive that controlled man, and by knowing this man should confront it. In fact Freud's psychoanalytic theories were very foundational in the scientific study of the self and proceeded to shape many of the Modernist ideals, including Surrealist's.

In Freud's Outline of Psycho-Analysis, he explains his theory that the human mind is controlled primarily by unconscious impulses which help in determining the majority of man's actions. Freud divides man's nature into three parts: the id, ego, and super ego. The id "contains everything that is inherited, that is present at birth, that is laid down in the constitution - above all, therefore, the instincts." This is the determining factor in many of man's actions, as well as where 
the majority of unconscious human impulses and desires stem from. The ego, Freud states, is the "intermediary between the id and the external world." The ego stores one's experiences and helps him adapt to his circumstances. The job of the ego is to control and prioritize a person's instincts, as well as seek pleasure. The super ego is purely a matter of external influence on the self. Freud states that the super ego is shaped mostly by parental influence, but also "later successors, teachers, and admired social ideals." Freud states that the id, ego, and super ego work together and regulate every aspect of the human brain.

Moreover, in Surrealist's mind the belief in absolute reality was being replaced with a subjective and relative reality. Subsequently ironic mockery of the past ideals emerged in both literature and artwork, in which the new mission was to dig deeply into the imaginative, examining the great mysteries of what is above and beyond the reality to which human perception is limited. The surrealist artwork was incredibly focused on the psyche, most of it being dream oriented with a strong focus on altered states of consciousness.

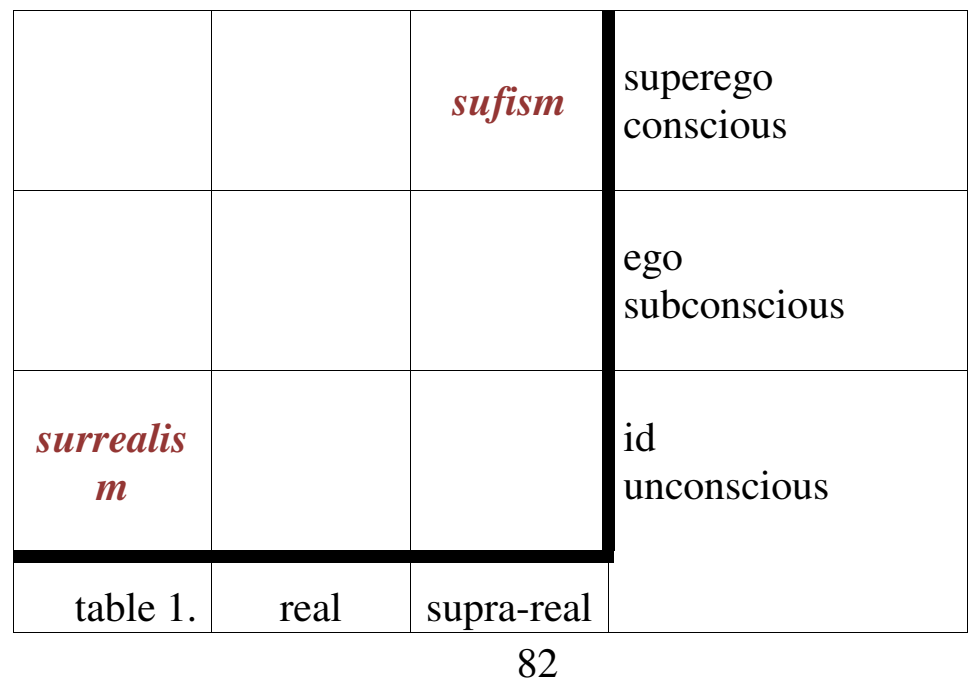




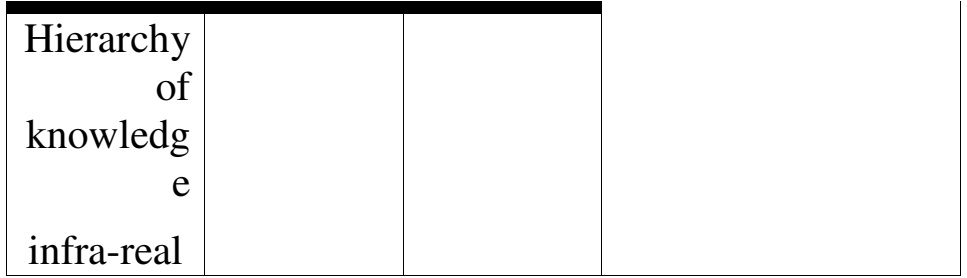

The surrealists, greatly influenced by Freud's ideas, created artworks which portrayed a combination of objective reality and the unconscious, bizarre reality of the mind.

According to critics, much of surrealists artworks, are bluntly and disturbingly sexual, erotic and sadistic with no emphasis on beauty, focusing on the chaos of the human psyche. Dali, as a great representative of the movement, seems to paint as if he were trying to put his id onto paper. The chaotic primal instincts that Freud claims make up the core of human being are clearly reflected in Dali's fascination with the juxtaposition of love and death, as well as the beautiful and repulsive.

Surrealist's focus on the chaos of the human psyche is very contrary to the Sufi's focus on the beauty of existence, annihilation of self and subsistence in unity. While the former attempts to point the disturbing paradoxes of reality, the latter embraces the paradoxical moment of amphibole, a sacred experience of tawhild where the Divine being is simultaneously the Loved, the Lover and the Love itself. (Baqlī's theory of iltibās) The grand paradox of the multiplicity of the Unique and the identity of the Multiple is indisputably the permeating theme of Sufism shat'hiat. Moreover, despite Surrealists hypothesis that individual reality is all that is real, for Sufis every atom of being manifests a divine attribute and to perceive the whole theophany, one should experience selflessness and fathom his 
nothingness. A schematic representation elucidates the remoteness of these two realms.

In table 1 , the vertical bold side signifies perception faculties, including self, reason and heart;

and the horizontal bold line indicates three domains of knowledge.

\begin{tabular}{|c|c|c|c|}
\hline $\begin{array}{l}\text { immanence } \\
\text { tashbīh }\end{array}$ & $\begin{array}{c}\text { transcendence } \\
\text { tanzīh }\end{array}$ & $\begin{array}{l}\text { unity } \\
\text { tawhìd }\end{array}$ & heart \\
\hline $\begin{array}{l}\text { imagination } \\
\text { wahm }\end{array}$ & $\begin{array}{l}\text { realization } \\
\text { fahm }\end{array}$ & $\begin{array}{l}\text { inspiration } \\
\quad \bar{l} l h \bar{a} m\end{array}$ & reason \\
\hline $\begin{array}{l}\text { self-gratification } \\
\text { inānīat }\end{array}$ & $\begin{array}{l}\text { submission } \\
\text { obūdīat }\end{array}$ & $\begin{array}{l}\text { wonderment } \\
\text { hayrat }\end{array}$ & self \\
\hline virtual & actual & factua & \\
\hline
\end{tabular}

According to Sufism teaching, self or nafs is considered to be the lowest principle of man, proceeding to reason or intellect, ' $a q l$ and heart or qalb. This classification is the foundation of later, more complicated systems; as in one example nafs associates with the zālim (tyrant), 'aql with the muqtasid (moderate), and qalb with the sābiq (preceding one, winner); the zâlim loves God for his own sake, the muqtasid loves Him for Himself, and the sābiq annihilates his own will in God's will.

table 2. Surrealism vs. Sufism

The self or nafs is the aspect of the psyche that can be viewed along a continuum and has the potential of functioning from the grossest to the highest level. The self at its lowest level refers to traits and tendencies which are controlled by emotions, desires and its gratification. Sufi psychology 
identifies multiple levels of the nafs, which have been identified in the Quran. The process of growth depends on working through these levels.Furthermore, for an evolving soul, reason or' aql offers a different approach to recognition . The intellect is the fundamental rational faculty which enables man to generalize and form concepts and gain knowledge, even though limitedly. He perceives through it the things that cannot be recognized through the senses. As with the unenlightened reason or the reason of the worldly life (or the worldly reason), man is engulfed the lowest of the lows, the reason which has been freed from the influences of carnality and lust and which has gained a certain degree of transcendence is a companion of the heart from a few steps behind. For Sufi, heart or qalb, is the most subtle and resolute approach for obtaining knowledge or ma'refah. In fact, it is through this faculty that Sufi gets closer to his Beloved and finally abides in His Unity.

As the table depicts, every one of the aforementioned faculties could imply different outcome when deployed on each of the threefold of knowledge domain: virtual reality or infra-real, actual reality and supra or sur reality. Pertinent to this paper, when the self tackles with actual reality, it accepts its own weakness and bends in obedience (bows in homage). However, confronting with virtual veracity, self-importance leads to narcissism and, on the other hand, even the tamed and disciplined self simply cannot imbibe supra real knowledge and halts in wonderment.

Table 2 illustrates the same theme (subject-matter) whereas Sufi perception faculties are replaced by their corresponding Freudian threefold of man's psyche: id, ego and superego which are comparatively ascribed to unconscious, subconscious and conscious respectively. In this table the hashed area is, more or less, the scope of Modernism, in which Surrealism resides. As 
mentioned earlier, Surrealists were inspired by the belief that the concepts of chance and unconscious were the only way of achieving true knowledge. Conscious and even subconscious controls over composition were suppressed in order to give free rein to unconscious imagery and associations. This is evident in many works of surrealism representatives such as Breton and Dali "whose inspiration comes from tapping into the unconscious psyche" (Johnson, 2007) and repression of the superego. According to experts, Dali, akin to other surrealists, "seems to paint as if he were trying to put his id onto paper." (ibid) Contentious however, surrealism positioning in infra-real extent is predicated on its "determination to attribute every reflex and disposition of the soul to mean causes and to exclude spiritual factors." (Schuan, 1966, 99) This attitude leads to relativism whereby everything becomes

the fruit of a contingent elaboration: Revelation becomes poetry, the Religions are inventions, sages are "thinkers"... infallibility and inspiration do not exist, error becomes a quantitative and "interesting" contribution to "culture"... there is... a denial of every supernatural, or even suprasensory, cause and by the same token of every principal truth.(ibid, 154-155)

This is obviously in contrast with Surrealism pretention, that is to embark upon supra-real hemisphere. The confusion of psychic plane, the arena in which the more or less accidental subjectivities of the individual id come to play in the depths of the unconscious, and infinite realm of the spirit which in terms of the human individual, is signaled by the capacity for the plenary experience and which is thus marked by an inward illimitation and transcendence, is discussed in length by Renē Guēnon.

Back to the obverse side, shat'hiat, steeped in Sufism doctrines, is the symbolic expression of infinite reaches of the 
disciplined soul who sees nothing other than God. Therefore, it resides in the furthermost distant to surrealism where one takes oneself for a god. In other words, despite all superficial affinities in techniques, the latter derived from radically different principle, applied different therapies and pursued different ends. Thus, it is a great mistake to falsify ecstatic ejaculations of Sufism with material discoveries of surrealist thought. These two realms seek diverse avenues of knowledge and the dichotomy between them is perpetual.

Zahra Abdoll

Department of Comparative and Analytic History of Islamic Art in Faculty of Arts, Shahed University, Tehran, Iran . Email: zahraabdollah@yahoo.ca 


\section{References}

Adamowicz, Elza. (1998). Surrealist collage in text and image. Cambridge University Press.

Anvar Chenderoff, Leili. (2007). Wondrous images:

Surrealism and the imaginal in Rumi's poetic imagery. INALCO, France.

Baqli Shirazi, Ruzbehan. (1966). Sharh-e shathiyat, ed.

Henry Corbin. Iran-France Institute, Tehran.

Breton, Andre. (1960). Nadja. trans. Richard Howard.

Grove Press.

Breton, Andre, Seaver, R., Lane, H.R. (1972). Manifestoes of Surrealism. trans. Richard Seaver and Helen R.

Lane. University of Michigan Press.

Carrette, J.R. (2002). Surrealism and the Religious Imagination. Foucault and Religion. Routledge, pp. 44-63.

Cheetham, Tom. (1972). Henry Corbin on Ruzbehan Baqli of Shiraz.

Corbin, Henry. (1972). En Islam Iranien: Aspects spirituels et philosophiques, Tome III: Les fideles d'amour et

Shi'isme et sufisme. Livre III: Ruzbehan Baqli

Shirazi and the Sufism of the Fideles d'Amour. tran. Tom Cheetham. Paris, Gallimard.

Duplessis, Y. (1978). Surrealism. Westport, CT:

Greenwood Press.

Ernst, Carl W. (1985). Words of Ecstasy in Sufism. Suny Press. Albany.

Esmaili, Esmat, Ali Madadi, Mona. (2006). Surrealism and Shams Tabrizi's discourses. Hafiz Monthly. 33, 50-58.

Eve, Paul. (1970). Surrealism. Edito Service. SA. Geneva.

Fanes, Felix. (2007). Salvador Dali: the construction of the Image. Yale Univ. Press. 
Frager, Rebert. (1999). Heart, Self and Soul. Quest

Books. Theosophical Publishing House.

Gascoyne, David. (1978). English and American Surrealist Poetry. ed. E.B. Germain. Penguin Books.

Guinhut, Jean-Pierre. (1998). The Man Who Loved Too Much. Azerbaijan International. 6.3, 33-38.

Johnson, Layph. (2007). The Enlightenment to Modernism: A Brief Examination of this

Revolution in Thought and Society. Socyberty Pub.

Kadkani, M.R.S. (2001). Searching for Meaning in Nonsense. Journal of the Faculty of Literature and Humanities. Teacher Training Univ. 9(32), 23-52.

Khatib, Kate. (2006). Surrealism and the Politics of Equality.

Political Theologies. ed. L.E. Sullivan and Hent de Vries.

Lautréamont, C. (2004). Maldoror and the Complete

Works of the Comte de Lautréamont. trans. Alexis Lykiard. Exact Change Pub.

Lear, Edward. (1967). The story of the four little children who went round the world. H. Quist. Crown Pub. New York.

Nadeau, Maurice. (1968). The History of Surrealism. trans. Richard Howard. London: Jonathan Cape.

Nasr, S.H. (1979). Reflections on Islam and Modern Thought. The Islamic Quarterly XXIII, iii, 119131.

Nelson, R.F, Fisher, W.B., Boyle, J.A. (1975). The Cambridge History of Iran. Cambridge University Press.

Rimbaud, Arthur, et. al. (1974). A Season in Hell and the Illuminations. trans. Enid Rhodes. Oxford University Press.

Rumi, Muhammad Jalaludin. (1898). The Spiritual Couplets. 
trans. E.H. Whinfield. Book IV.

Rumi, Muhammad Jalaludin. (1990). Mathnawi. trans. Reynold A. Nicholson. Gibb Memorial Trust.

Saladyga, S.F. (2006). The Mindset of Salvador Dalí. Lamplighter, 1(3).

Schuan, F. (1966). The Psychological Imposture. Tomorrow XIV, ii.

Sells, Michael. (1996). Early Islamic Mysticism. Paulist Press. NY.

Shams, Muhammad b. Ali b. Malekdad Tabrizi. (1998). Shams Discourses. ed. Modares Sadeghi, Jafar. Tehran: Markaz.

Shields, Rob. (1999). Lefebure, Love and Struggle. Spatial Dialectics. Routledge. 